\title{
Az egészségbiztosítási gyógyszerkiadások alakulása Magyarországon
}

\author{
dr. Eisingerné Balassa Boglárka dr. ${ }^{1}$ - Csákvári Tímea ${ }^{2}$ - Ágoston István dr. ${ }^{2}$ \\ ${ }^{1}$ Széchenyi István Egyetem, Kautz Gyula Gazdaságtudományi Kar, Győr \\ ${ }_{2}^{2}$ Pécsi Tudományegyetem, Egészségtudományi Kar, Egészségbiztosítási Intézet, Pécs
}

Bevezetés: Hazánkban is egyre nagyobb jelentőségű az egészségügyi kiadások, ezen belül a gyógyszerekre fordított társadalombiztosítási támogatások kérdése.

Célkitüzés: Vizsgálatunk célja, hogy feltárjuk Magyarország 2010 és 2016 közötti egészségbiztosítási kiadásainak, valamint a gyógyszerekre adott társadalombiztosítási támogatásoknak a mértékét.

Adatok és módszerek: Az adatok a Nemzeti Egészségbiztosítási Alapkezelő, valamint a Központi Statisztikai Hivatal adatbázisából származnak. Az elemzés során a 2010 és 2016 közötti időszakot vizsgáltuk. Elemeztük az egészségügyi kiadásokat a bruttó hazai termék (GDP) arányában, a bruttó fogyasztói áron számított gyógyszerforgalom és társadalombiztosítási támogatás változását, valamint területi egyenlőtlenségeiket. A tanulmány elkészítése során leíró statisztikai módszereket alkalmaztunk.

Eredmények: Magyarországon az Egészségbiztosítási Alap kiadásai a GDP arányában a 2010. évi 5,5\%-ról 2016-ban 6,1\%-ra emelkedtek. A gyógyszerekre vonatkozó társadalombiztosítási támogatások összege 2013 óta emelkedik. A 10000 lakosra jutó legmagasabb társadalombiztosítási támogatás Baranya (405788 Ft/lakos) és Csongrád (384 724 Ft/lakos) megyében, valamint Budapesten (377 316 Ft/lakos) volt megfigyelhető. A legalacsonyabb társadalombiztosítási támogatást Nógrád (289 $168 \mathrm{Ft} /$ lakos) és Szabolcs-Szatmár-Bereg (271 $104 \mathrm{Ft} /$ lakos) megyében találtuk. Következtetés: Az egészségügyi és gyógyszerkiadások trendjei emelkedő tendenciát mutatnak. Mind a bruttó fogyasztói áron számított gyógyszerforgalom, mind a társadalombiztosítási támogatás esetében jelentős területi egyenlőtlenségeket találunk. Kívánatos lenne a prevenció elemeinek erősítése, az egészségtudatos életmód és a sportolás népszerúsítése. Orv Hetil. 2019; 160(Suppl 1): 49-54.

Kulcsszavak: gyógyszerforgalom, egészségügyi kiadások, társadalombiztosítási támogatás

\section{Health insurance pharmaceutical expenditures in Hungary}

Introduction: In Hungary, health expenditures - especially the question of health insurance subsidies for medicinal products -are becoming increasingly important.

Aim: The aim of our analysis is to reveal the state's health insurance expenditure between 2010 and 2016 as well as the amount of health insurance subsidies for medicinal products.

Data and methods: Data were derived from the database of the National Health Insurance Fund of Hungary and of the Hungarian Central Statistical Office. During the analysis we examined the period between 2010 and 2016. We analysed the health expenditures in proportion to the gross domestic product (GDP) as well as the changes of drug traffic based on gross consumer prices and those of health insurance subsidies, and also our regional inequalities. When writing the present study, we used descriptive statistical methods.

Results: The expenditures of the National Health Insurance Fund of Hungary significantly increased as proportions of the GDP from $5.5 \%$ in 2010 to $6.1 \%$ in 2016. The health insurance subsidies for medicinal products increased since 2013. The highest health insurance subsidies per 10000 inhabitants could be seen in Baranya (405 788 HUF/ inhabitant) and Csongrád (384 724 HUF/inhabitant) counties and in Budapest (377 316 HUF/inhabitant). The lowest health insurance subsidies were found in Nógrád (289 168 HUF/inhabitant) and Szabolcs-Szatmár-Bereg (271 $104 \mathrm{HUF} /$ inhabitant) counties.

Conclusion: The trends of health and drug expenditure show a growing tendency. We can find significant regional inequalities in case of both the drug traffic based on gross consumer prices and the health insurance subsidies. It would be needed to strengthen the elements of prevention, and to popularize health-conscious lifestyle and doing sports.

Keywords: drug consumption, health expenditure, social insurance subsidy

Eisingerné Balassa B, Csákvári T, Ágoston I. [Health insurance pharmaceutical expenditures in Hungary]. Orv Hetil. 2019; 160(Suppl 1): 49-54. 


\section{Rövidítések}

E. Alap $=$ Egészségbiztosítási Alap; GDP $=$ (gross domestic product) bruttó hazai termék; NEAK = Nemzeti Egészségbiztosítási Alapkezelő; OECD $=($ Organisation for Economic Co-operation and Development) Gazdasági Együttmúködési és Fejlesztési Szervezet; OEP = Országos Egészségpénztár; TB = társadalombiztosítás

Az elöregedő társadalmakban, mint amilyen a magyar is, egyre inkább felértékelődik az egészségügyi szolgáltatások szerepe, jelentősége, maga után vonva az egészségügyi kiadások emelkedését. Az egészségügyi kiadások emelkedése nemcsak Magyarországra jellemző. Az Eurostat felmérte, hogy 2015-ben hogyan alakultak a folyó egészségügyi kiadások az adott országok GDP \%-ában [1]. Az ebben a felmérésben szereplő 26 európai ország közül Magyarország a 19. helyen szerepelt, csak hét ország költött kevesebbet az egészségügyi kiadásokra a GDP-jük százalékában, mégpedig Csehország, Szlovákia, Észtország, Lengyelország, Luxemburg, Lettország és Törökország. Az OECD által 2016-ban készített felmérésben szereplő becsült adatok is hasonló eredményeket mutattak.

Az egészségügyi kiadások egyik leglényegesebb összetevőjét képezik a gyógyszerekre vonatkozó kiadások, amelyek magukban foglalják a gyógyszerek kiváltásához kapcsolt társadalombiztosítási támogatásokat, valamint a lakosság közvetlen gyógyszerkiadásait egyaránt. A társadalombiztosítás által nyújtott gyógyszerár-támogatások lehetővé teszik a gyógyszerekhez való hozzáférést azon társadalmi csoportoknak is, akiknek nehézséget okozna a gyógyszerek teljes árának megfizetése. A magyar gyógyszerár-támogatási rendszer rendkívül összetett, a gyógyszerek támogatási formáját két kategóriába lehet csoportosítani. Az első csoportba az indikációhoz kötött támogatások tartoznak: vannak a kiemelt 100\%-os és az emelt 90\%-os, 70\%-os és 50\%-os támogatások. A második csoportba pedig a normatív támogatások tartoznak, idesorolható a normatív $80 \%$-os, $55 \%$-os, $25 \%$-os, valamint a támogatási érték nélküli 0\%-os kategória.

Tekintettel a gyógyszerkiadásoknak az egészségügyi kiadások közötti jelentős szerepére, az államháztartási egyensúly megörzése érdekében célszerü szoros kontrollt gyakorolni a gyógyszerekre vonatkozó társadalombiztosítási támogatásokra vonatkozóan. Az emelkedés dinamikáját jól példázza, hogy míg 1995-ben 80 milliárd forint volt, addig 2009-ben 390 milliárd forintra nőtt a gyógyszerekre vonatkozó társadalombiztosítási támogatás mértéke. A vizsgált időszakban a 2011. évi Szél Kálmán Terv foglalkozott a költségvetési egyensúly megteremtésével és az államadósság csökkentésével; érdemesnek tartjuk megvizsgálni annak elvárt és valós hatását.

Vizsgálatunk célja volt, hogy felmérjük, hogyan alakultak az elmúlt években Magyarország egészségügyi kiadásai, valamint a gyógyszerekre adott társadalombiztosítási támogatások, tekintve, hogy az Egészségbiztosí- tási Alap (E. Alap) költségvetésének egyéb fejezeteit, a hazai egészségügyi rendszer felépítését [2-6], múködését [7-9] és finanszírozásának további részleteit $[10,11]$ számos tanulmány érintette.

\section{Adatok és módszerek}

A tanulmány elkészítése során leíró statisztikai módszereket alkalmaztunk, a könnyebb áttekinthetőség érdekében idősorokba rendezett adatainkat diagramok segítségével ábrázoltuk. A tanulmány elkészítéséhez felhasznált adatok a Nemzeti Egészségbiztosítási Alapkezelő (NEAK) adatbázisából [12], valamint a Központi Statisztikai Hivatal adataiból [13] származnak. Az elemzés során a 2010 és 2016 közötti időszakot vizsgáltuk.

Első lépésben meghatároztuk az E. Alap kiadásait a bruttó hazai termék (gross domestic product, GDP) százalékos arányában. Az E. Alap kiadásaiban a pénzbeli és természetbeni kiadások egyaránt szerepelnek ( 1 . ábra).

A gyógyszerek támogatására fordított társadalombiztosítási támogatás alakulását a 2010 és 2016 közötti időszakban vizsgáltuk. Itt a vényköteles, közforgalmú gyógyszertárban a lakosság által kiváltott gyógyszerekre kifizetett társadalombiztosítási támogatás összege szere-

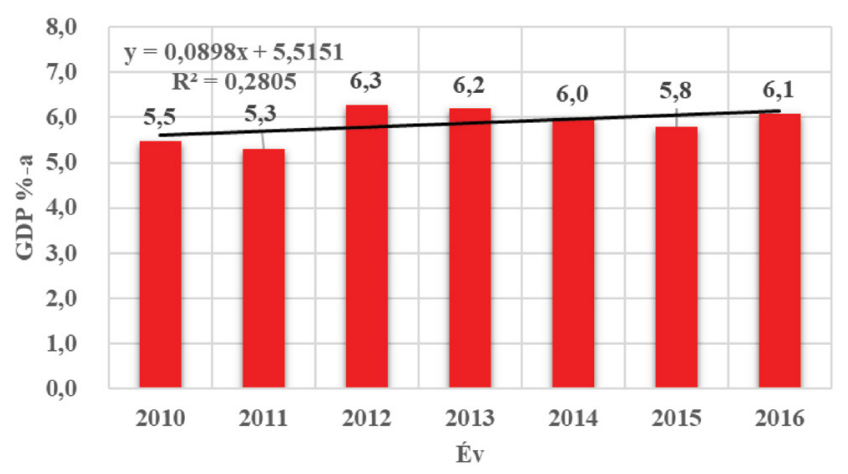

1. ábra $\quad$ Az Egészségbiztosítási Alap kiadásainak alakulása Magyarországon a bruttó hazai termék (GDP) százalékos arányában 2010 és 2016 között

Forrás: Nemzeti Egészségbiztosítási Alapkezelő

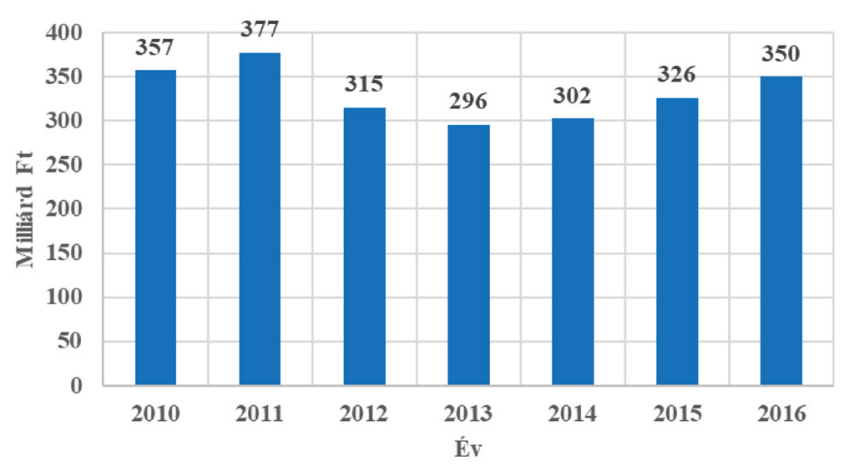

2. ábra $\quad$ A gyógyszerek támogatására fordított társadalombiztosítási támogatás alakulása 2010 és 2016 között

Forrás: Nemzeti Egészségbiztosítási Alapkezeló 
pel. 2012 és 2013 között több, korábban közforgalmú gyógyszertárban forgalmazott gyógyszerkészítmény azonban átkerült a tételes elszámolás alá eső gyógyszerek közé. A bruttó fogyasztói áron számolt gyógyszerforgalom egyfajta piacivolumen-indikátorként került meghatározásra (2. és 3. ábra).

A követő lépésben a 10000 lakosra jutó bruttó fogyasztói áron számított gyógyszerforgalom (4. ábra) és társadalombiztosítási támogatás (5. ábra) igénybevételének területi egyenlőtlenségeit elemeztük. Ehhez a 10000 lakosra vetített bruttó fogyasztói áron számított gyógyszerforgalmat és társadalombiztosítási támogatást határoztuk meg megyei bontásban. A 10000 lakosra vetített adatok közlésénél az egyes megyék népességszámára vonatkozó adatok a Központi Statisztikai Hivatal interneten elérhető adataiból származnak [14].

Meghatároztuk továbbá a 10000 lakosra jutó bruttó fogyasztói áron számított gyógyszerforgalom és a társadalombiztosítási támogatás összege közötti összefüggést, korrelációs együttható számításával.

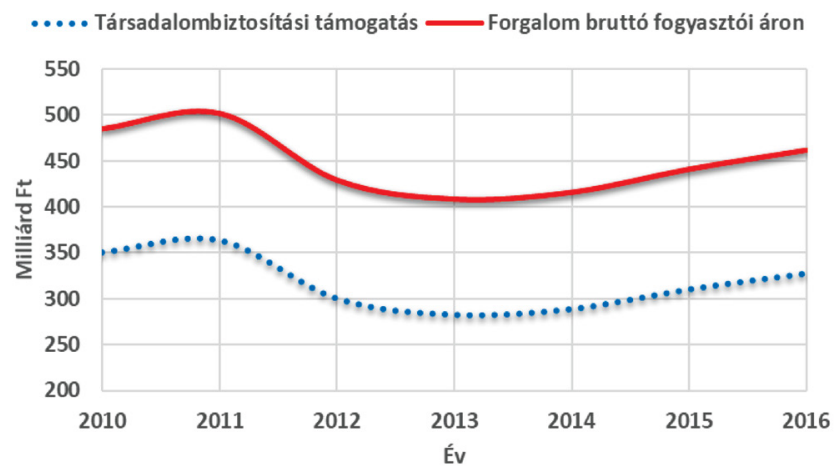

3. ábra

A lakosság által közforgalmú gyógyszertárakban kiváltott gyógyszerkészítmények forgalma bruttó fogyasztói áron és társadalombiztosítási támogatásuk

Forrás: Nemzeti Egészségbiztosítási Alapkezelő

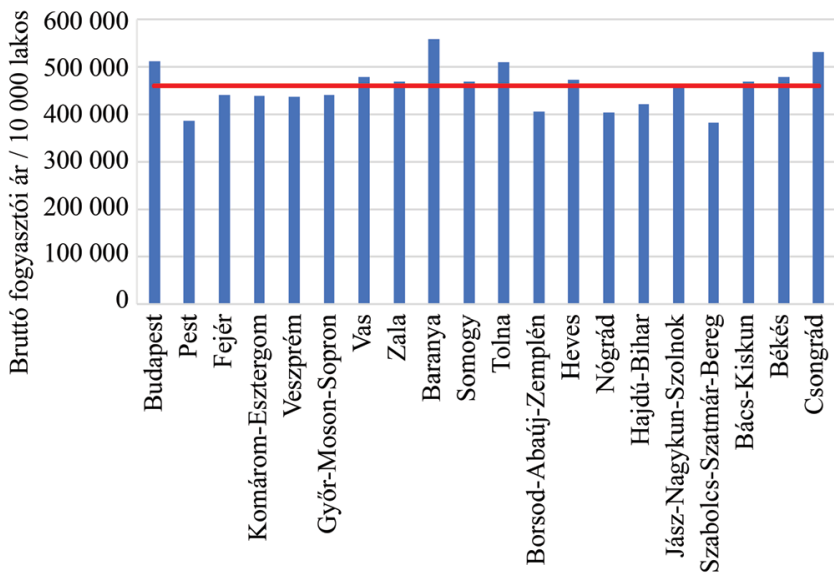

4. ábra

\footnotetext{
10000 lakosra jutó bruttó fogyasztói áron számított gyógyszerforgalom

Forrás: Nemzeti Egészségbiztosítási Alapkezelő
}

A gyógyszerek árával, ártámogatási rendszerével számos tanulmány foglalkozik [15-20], mint ahogy a magyar egészségügyi rendszer múködésének [21-24] és finanszírozásának [25-30] további részleteivel is, ezekre itt most nem térünk ki.

\section{Eredmények}

Elsőként a magyarországi E. Alap kiadásait vizsgáltuk a GDP-hez viszonyított százalékos arányban a 2010 és 2016 közötti időszakban, amelyeket az 1. ábrán szemléltetünk. A vizsgált időszakban az E. Alap kiadásai, amelyek magukban foglalják a pénzbeli és természetbeni kiadásokat egyaránt, 5,5\% és 6,1\% között alakultak. A legalacsonyabb egészségügyi kiadásra vonatkozó adatot 2011-ben találtuk $(5,3 \%)$, amely fokozatosan emelkedett 6,1\%-ra 2016-ra. A 2010 és 2016 közötti trend $\left(\mathrm{R}^{2}=\right.$ $0,28)$ határozott emelkedést mutat. Az egészségügyi kiadásokat közvetlenül érintik a társadalombiztosítás által nyújtott egészségügyi ellátásokon, támogatásokon keresztül a költségvetési egyensúly megteremtése érdekében tett központi intézkedések.

A 2. ábrán látható a gyógyszerek támogatására fordított kiadások alakulása Magyarországon a 2010 és 2016 közötti időszakban. Megfigyelhető, hogy a gyógyszerek társadalombiztosítási támogatásának összege jelentősen növekedett. A kormány 2011-ben ismertette új államadósság-csökkentő tervét, a Széll Kálmán Tervet, mely kiemelten kezelte a gyógyszerekhez kapcsolódó társadalombiztosítási támogatások kérdését, és megoldási javaslatként magában foglalta a gyógyszerár-támogatási rendszer teljes átalakítását.

A lakosság által közforgalmú gyógyszertárakban kiváltott gyógyszerkészítmények forgalmi adatainak alakulását mutatja be a 3. ábra 2010 és 2016 között, milliárd forintban. Az ábrán látható, hogy az adott időszak forgalma bruttó fogyasztói áron és a kifizetett társadalombiztosítási támogatás értéke együtt mozog. A bruttó fo-

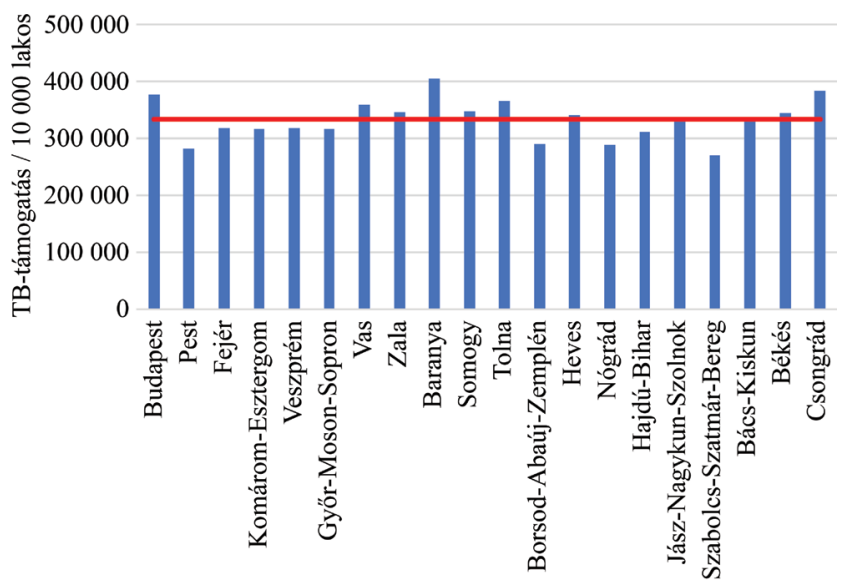

\begin{tabular}{l|l} 
5. ábra & 10000 lakosra jutó gyógyszer társadalombiztosítási támogatás
\end{tabular} Forrás: Nemzeti Egészségbiztosítási Alapkezeló 
gyasztói áron számított gyógyszerforgalom a legmagasabb értéket 501652 milliárd Ft-tal 2011-ben érte el. A bruttó fogyasztói áron számított gyógyszerforgalom összege a vizsgált időszakban 2013-ban volt a legalacsonyabb, 408408 milliárd Ft, azonban mind a gyógyszerforgalom, mind a kifizetett társadalombiztosítási támogatás 2013 óta folyamatosan növekvő tendenciát mutat.

A 10000 lakosra jutó bruttó fogyasztói áron számított gyógyszerforgalmat a 4. ábra szemlélteti. A legmagasabb gyógyszerforgalom Baranya (558 768 Ft/lakos) és Csongrád (531 $955 \mathrm{Ft} /$ lakos) megyében, valamint Budapesten (512 571 Ft/lakos) volt megfigyelhető. A legalacsonyabb gyógyszerforgalmat Pest $(386910 \mathrm{Ft} /$ lakos) és Szabolcs-Szatmár-Bereg (383 193 Ft/lakos) megyében találtuk. Az egy fơre jutó legalacsonyabb és legmagasabb gyógyszerforgalom között 46\%-os eltérés volt.

A 10000 lakosra jutó társadalombiztosítási támogatást az 5. ábra szemlélteti. A legmagasabb társadalombiztosítási támogatás Baranya (405 788 Ft/lakos) és Csongrád (384 $724 \mathrm{Ft} /$ lakos) megyében, valamint Budapesten (377 $316 \mathrm{Ft} /$ lakos) volt megfigyelhető. A legalacsonyabb társadalombiztosítási támogatást Nógrád (289 168 Ft/lakos) és Szabolcs-Szatmár-Bereg (271 104 Ft/lakos) megyében találtuk. Az egy főre jutó legalacsonyabb és legmagasabb gyógyszerforgalom között 50\%os eltérés volt.

A 10000 lakosra jutó bruttó fogyasztói áron számított gyógyszerforgalom és a társadalombiztosítási támogatás összege közötti összefüggés korrelációs együtthatója 0,988 lett. Vagyis nagyon szorosnak bizonyult az összefüggés a két változó között.

\section{Megbeszélés}

Tanulmányunk célja az volt, hogy a rendelkezésünkre álló adatok vizsgálatával feltárjuk, hogy van-e valamilyen kapcsolat a magyarországi E. Alap kiadásai, a gyógyszerekre vonatkozó támogatások között. A gyógyszerek árának emelkedéséből, a társadalombiztosítási támogatás intenzitásának ingadózó jellegéból fakadóan növekvő lakossági terhek, valamint az egyre szélesedő termékpaletta komoly kihívást jelent a közfinanszírozás számára.

2012 és 2013 között több, korábban közforgalmú gyógyszertárban forgalmazott gyógyszerkészítmény azonban átkerült a tételes elszámolás alá eső gyógyszerek közé, ami jelentős mértékben befolyásolta a gyógyszerkassza volumenét. A tételes elszámolás alá eső gyógyszerek finanszírozására az OEP 2011-ben 8,6 milliárd forintot költött, ami 2012-ben 32,4 milliárd forintra, 2013-ban 36,9 milliárd forintra, majd 2014-ben 48,1 milliárd forintra emelkedett. Ezen összegek - mivel nem a klasszikus gyógyszertári vénykiváltás során kifizetett TB-támogatást jelentenek - már nem jelennek meg a gyógyszerkassza kiadásai között.

A gyógyszerpiac területén a cél a profitszerzés, ezt azonban a fogyasztók védelme érdekében szigorú etikai előírások szabályozzák. Egy gyógyszer fontos és nagy kockázatú termék, hiszen az ember egészségének károsodását is okozhatja. A gyógyszer kiválasztásában és vásárlási folyamatában fontos szerepet tölt be az orvos vagy a gyógyszerész, hiszen az ő szakértelmük pótolhatatlan. Így elengedhetetlen, hogy a beteg bizalommal forduljon a szakemberek felé, hiszen nélkülük kiszolgáltatott. Gyógyszervásárlás során az ár másodlagos, bár a vény nélkül kapható gyógyszerek nagy választéka miatt akár döntő tényező is lehet, hiszen nem mindenki engedheti meg magának a jóval drágább gyógyszerek megvásárlását [31].

A vizsgált időszak végére az E. Alap kiadásai a GDP százalékos arányában és a társadalombiztosítási támogatás összege egyaránt megemelkedett. Ezen növekedések oka lehet az elöregedő magyar társadalom és a lakosság rossz egészségügyi állapota, valamint a gyakoribb daganatos és keringési megbetegedések, amelyek miatt a gyógyszerfogyasztás a jövőben várhatóan tovább növekszik [32-35]. Meglátásunk szerint mindez maga után vonhatja a társadalombiztosítási támogatások növelését, ami befolyásolhatja az államháztartási egyensúly fenntartását. A lakossági szükségletek átalakulása az egészségügyi ellátórendszerben is változásokat vetít előre, különösen a krónikus és rehabilitációs ellátások irányába [36-44].

A gyógyszerfogyasztási szokások és a társadalombiztosítási támogatás kérdésköre egy olyan urna alakú korfával rendelkező ország esetében, mint hazánk - mert a gyógyszerek részaránya az egyre növekvő számú nyugdíjaskorcsoport szempontjából kitüntetett jelentőségü - a fogyasztóiár-indexben az általános 2,9\%-os mértékú arány helyett a nyugdíjasok kiadási szerkezetében 6,2\%kal szerepel. Mindezek alapján elmondható, hogy mind az állam, mind a háztartások számára kívánatos lenne a prevenciós szemléletmód megerösítése. A betegségek kezelése helyett több figyelmet kellene fordítani a betegségek megelőzésére, valamint a nyugat-európai trendekhez hasonlóan szükséges lenne nagyobb energiát fektetni az egészséges életmód népszerüsítésébe, a sportoláshoz szükséges eszközök és infrastruktúra elérhetővé tételébe. A gyógyszerfogyasztás volumenének növelése nem pótolja a betegségek megelőzése, korai felismerése révén elérhető egészségnyereség mértékét [45-48].

Anyagi támogatás: A közlemény a Magyar Nemzeti Bank Pallas Athéné Innovációs és Geopolitikai Alapítványának (PAIGEO) pályázati támogatásával készült, „A pénzbeli és természetbeni ellátások arányai az Egészségbiztositási Alap költségvetésében a munkaeröpiaci folyamatok tükrében” címú 26/2017. (05.12.) kuratóriumihatározat-számú projekt keretében. 
Szerzôi munkamegosztás: A hipotézis kidolgozása: E. B. B., Á. I. Szakirodalomkutatás: E. B. B., Cs. T., Á. I. Adatelemzés, statisztika: E. B. B., Cs. T. A kézirat megszövegezése: E. B. B., Cs. T., Á. I.

Érdekeltségek: A szerzőknek nincsenek érdekeltségeik.

\section{Irodalom}

[1] OECD/European Observatory on Health Systems and Policies. Hungary: Country Health Profile 2017. State of Health in the EU. [Magyarország: Egészségügyi Országprofil 2017. State of Health in the EU.] OECD Publishing, Paris/European Observatory on Health Systems and Policies, Brussels, 2017. [Hungarian]

[2] Kovács G, Nogel M, Fáskerty É. Health and social rights handbook. [Egészségügyi és szociális jogi kézikönyv.] UniversitasGyőr Nonprofit Kft., Győr, 2017. [Hungarian]

[3] Kovács G. The basics of the health care system. In: Kovács G, Nogel M, Fáskerty É. Health and social rights. [Az egészségügyi ellátórendszer alapjai. In: Kovács G, Nogel M, Fáskerty É. [Egészségügyi és szociális jog.] Universitas-Győr Nonprofit Kft., Győr, 2017; pp. 120-133. [Hungarian]

[4] Kovács G, Nogel M, Fáskerty É. Health and social rights. [Egészségügyi és szociális jog.] Universitas-Győr Nonprofit Kft., Győr, 2017. [Hungarian]

[5] Kovács G. Professional requirements for health services. In: Kovács G, Nogel M, Fáskerty É. Health and social rights. [Az egészségügyi szolgáltatások szakmai követelményei. In: Kovács G, Nogel M, Fáskerty É. [Egészségügyi és szociális jog.] Universitas-Győr Nonprofit Kft., Győr, 2017; pp. 134-137. [Hungarian]

[6] Gellérné Lukács É, Gyeney L, Kovács G, et al. Third-country nationals in the Hungarian public health care sector. New Med. 2015; 19: 29-36.

[7] Kovács G. Data protection on health care: the outline of health care data management. [Adatvédelem az egészségügyben: $\mathrm{Az}$ egészségügyi adatkezelés vázlata.] Med et Jur. 2011;2(1): 1618. [Hungarian]

[8] Kovács G. Sectorial data protection: health care data protection. [Szektorális adatvédelem: egészségügyi adatvédelem.] Med et Jur. 2011; 2(2): 17-19. [Hungarian]

[9] Kovács G. Special issues in health care data protection. [Speciális területek az egészségügyi adatkezelésben.] Med et Jur. 2011; 2: 14-17. [Hungarian]

[10] Kovács G, Nogel M. Activity of forensic experts and quality assurance in Hungary. Forensic Sci Int. 2017; 277: 257-258.

[11] Cserháti P, Laczkó T, Vendégh Zs, et al. Problems of rehabilitation in our coutry and the possibilities of its further development in cases of hip fractures. [A combnyaktáji törés utáni rehabilitáció hazai problémái és a fejlesztés lehetőségei.] Magy Traumatol. 1992; 35: 149-154. [Hungarian]

[12] Data on drug traffic 2010-2016. [Gyógyszerforgalmi adatok 2010-2016.] Nemzeti Egészségbiztosítási Alapkezelő, Budapest, 2016. [Hungarian]

[13] The development of health care expenditures in Hungary, 2010 2015. [Az egészségügyi kiadások alakulása Magyarországon, 2010-2015.] Statisztikai Tükör 2017. március 21. [Hungarian]

[14] Population by gender in 2001-2018. [A lakónépesség nem szerint 2001-2018.] Központi Statisztikai Hivatal, STADAT, Budapest, 2018. [Hungarian]

[15] About the price of drugs. [A gyógyszerek áráról.] Magyar Gyógyszergyártók Országos Szövetsége, Budapest, 2009. [Hungarian]

[16] Gulácsi L, Dávid T, Dózsa C. Pricing and reimbursement of drugs and medical devices in Hungary. Eur J Health Econ. 2002; 3: $271-278$
[17] Endrei D, Molics B, Ágoston I. Multicriteria decision analysis in the reimbursement of new medical technologies: real-world experiences from Hungary. Value Health 2014; 17: 487-489.

[18] Répásy B, Endrei D, Zemplényi A, et al. The effect of generic price competition on drug consumption and health insurance pharmaceutical expenditures in Hungary. [Generikus árverseny hatása a gyógyszerforgalomra és a társadalombiztosítási támogatás kiáramlásra Magyarországon.] Acta Pharm Hung. 2015; 85: 83-88. [Hungarian]

[19] Hornyák L, Nagy Zs, Tálos Zs, et al. Experiences with price competition of biosimilar drugs in Hungary. [A biohasonló gyógyszerek árversenyének tapasztalatai Magyarországon.] Acta Pharm Hung. 2014; 84: 83-87. [Hungarian]

[20] Répásy B, Endrei D, Zemplényi A, et al. The patients' cost of the montelukast therapy due to the generic substitution. [A montelukasztterápia betegterheinek változása a generikus árverseny hatására.] Orv Hetil. 2018; 159: 682-687. [Hungarian]

[21] Boncz I, Sebestyén A. Health services research in Hungary. Med J Aust. 2006; 184: 646-647.

[22] Boncz I., Evetovits T, Dózsa Cs, et al. The Hungarian Care Managing Organization Pilot Program. Value Health Reg Issues. $2015 ; 7: 27-33$.

[23] Kriszbacher I, Oláh A, Bódis J, et al. Health sciences research in Hungary. CMAJ 2007; 176: 809-812.

[24] Csanádi M, Löblová O, Ozierański $\mathrm{P}$, et al. When health technology assessment is confidential and experts have no power: the case of Hungary. Health Econ Policy Law 2018 Mar 26. doi: 10.1017/S1744133118000051. [Epub ahead of print]

[25] Boncz I, Nagy J, Sebestyén A, et al. Financing of health care services in Hungary. Eur J Health Econ. 2004; 5: 252-258.

[26] Inotai A, Nguyen HT, Hidayat B, et al. Guidance toward the implementation of multicriteria decision analysis framework in developing countries. Expert Rev Pharmacoecon Outcomes Res. 2018; 18: 585-592.

[27] Boncz I, Kaló Z, Mohamed Ibrahim MIB, et al. Further steps in the development of pharmacoeconomics, outcomes research, and health technology assessment in Central and Eastern Europe, Western Asia, and Africa. Value Health Reg Issues 2013; 2: 169170.

[28] Boncz I, Dózsa C, Kaló Z, et al. Development of health economics in Hungary between 1990-2006. Eur J Health Econ. 2006; 7(Suppl 1): S4-S6

[29] Boncz I, Sebestyén A. Financial deficits in the health services of the UK and Hungary. Lancet 2006; 368: 917-918.

[30] Boncz I, Nagy J, Körösi L, et al. The effect of the introduction of visit fee on the number of patient-visits to outpatient care departments in Hungary. Value Health 2008; 11: A368-A369.

[31] Gál-Knippel B. The transformation of the Hungarian pharmaceutical market between 2007 and 2010 in the light of gynecological products. Doctoral dissertation. [A magyarországi gyógyszerpiac átalakulása 2007 és 2010 között a nőgyógyászati készítmények tükrében. Doktori értekezés.] Nyugat-magyarországi Egyetem, Közgazdaságtudományi Kar, Széchenyi István Gazdálkodás- és Szervezéstudományok Doktori Iskola, Sopron, 2011. [Hungarian]

[32] Boncz I, Sebestyén A, Döbrőssy L, et al. The role of immunochemical testing for colorectal cancer. Lancet Oncol. 2006; 7: 363-364.

[33] Boncz I. Prevention of cervical cancer in low-resource settings. JAMA 2006; 295: 1248

[34] Boncz I, Endrei D, Ágoston I, et al. Annual health insurance cost of breast cancer treatment in Hungary. Value Health 2014; 17: A735.

[35] Boncz I, Sebestyén A, Pintér I, et al Age group-specific gap between treatment cost of and mortality due to breast and colorectal cancer. J Clin Oncol. 2007; 25: 4501-4502.

[36] Molics B, Kránicz J, Schmidt B, et al. Utilization of physiotherapy services in case of trauma disorders of the lower extremity in 
the outpatient care. [A fizioterápiás jellegú tevékenységek igénybevételi mutatói a járóbeteg-szakellátásban az alsó végtag traumatológiai kórképei esetében.] Orv Hetil. 2013; 154: 985-992. [Hungarian]

[37] Sallai JR, Hunka A, Héjj G, et al. Helping reintegration of patients suffering from chronic musculoskeletal diseases with decreased working ability in the National Institute of Rheumatology and Physiotherapy, Budapest, Hungary. [Csökkent munkaképességú krónikus mozgásszervi betegek reintegrációjának elősegítése.] Orv Hetil. 2017; 158: 662-667. [Hungarian]

[38] Péter I, Jagicza A, Ajtay Z, et al. Balneotherapy in psoriasis rehabilitation. In Vivo 2017; 31: 1163-1168.

[39] Poór AK, Sárdy M, Cserni T, et al. Assessment of health-related quality of life in psoriasis patients in Hungary. [Psoriasisban szenvedő betegek életminőségének vizsgálata Magyarországon.] Orv Hetil. 2018; 159: 837-846. [Hungarian]

[40] Melczer C, Melczer L, Goják I, et al. Telemetry data based on comparative study of physical activity in patients with resynchronization device. [Reszinkronizációs készülékkel élő betegek fizikai aktivitásának összehasonlító vizsgálata telemetriás adatok alapján.] Orv Hetil. 2017; 158: 748-753. [Hungarian]

[41] Apor P. Cardiac rehabilitation and its sporty face. [A szívbetegek rehabilitációjának sportos arca.] Orv Hetil. 2018; 159: 13461352. [Hungarian]

[42] Sebestyén A, Mester S, Vokó Z, et al. Wintertime surgery increases the risk of conversion to hip arthroplasty after internal fixation of femoral neck fracture. Osteoporos Int. 2015; 26: 1109-1117.
[43] Bergier B, Bergier J, Niźnikowska E, et al. Differences in physical activity and nutrition- and silhouette-related behaviours in male and female students in selected European countries. Ann Agric Environ Med. 2018; 25: 176-181.

[44] Molics B, Boncz I, Leidecker E, et al. Health insurance aspects of physiotherapeutic care of neurology disorders in outpatient care. [A neurológiai kórképek fizioterápiás ellátásának egészségbiztosítási vonatkozásai a járóbeteg-szakellátásban.] Ideggyogy Szle. 2015; 68: 399-408. [Hungarian]

[45] Boncz I, Vajda R, Ágoston I, et al. Changes in the health status of the population of Central and Eastern European countries between 1990 and 2010. Eur J Health Econ. 2014; 15(Suppl 1): S137-S141.

[46] Endrei D, Zemplényi A, Molics B, et al. The effect of performance-volume limit on the DRG based acute care hospital financing in Hungary. Health Policy 2014; 115: 152-156.

[47] Boncz I, Brodszky V, Péntek M, et al. The disease burden of colorectal cancer in Hungary. Eur J Health Econ. 2010; 10(Suppl 1): S35-S40.

[48] Boncz I, Sebestyén A, Döbrőssy L, et al. The organisation and results of first screening round of the Hungarian nationwide organised breast cancer screening programme. Ann Oncol. 2007; 18: 795-799.

(dr. Eisingerné Balassa Boglárka dr., Gyơr, Egyetem tér 1., 9026 e-mail: eisingerne@sze.hu)

A cikk a Creative Commons Attribution-NonCommercial 4.0 International License (https://creativecommons.org/licenses/by-nc/4.0) feltételei szerint publikált Open Access közlemény, melynek szellemében a cikk nem kereskedelmi célból bármilyen médiumban szabadon felhasználható, megosztható és újraközölhető, feltéve, hogy az eredeti szerző és a közlés helye, illetve a CC License linkje és az esetlegesen végrehajtott módositások feltüntetésre kerülnek. 